\title{
ECONOMETRIC ANALYSIS OF INTEGRATION OF SELECTED NEW EU MEMBER GEE STOCK MARKETS WITH GLOBAL STOCK MARKET AND EUROZONE: IMPACT OF GLOBAL FINANCIAL GRISIS
}

\author{
Jan Sucháček ${ }^{1 *}$, Jaroslav Koutský2 ${ }^{2}$ Lorena Caridad Lopéz del Río ${ }^{3}$ \\ and Petr Sed'a ${ }^{4}$ \\ ${ }^{1)}$ Masaryk University, Brno, Czech Republic \\ 2) Jan Evangelista Purkyně University in Ústí nad Labem, Ústí nad Labem, \\ Czech Republic \\ ${ }^{3)}$ University of Córdoba, Córdoba, Spain \\ ${ }^{4)} V S ̌ B-T e c h n i c a l$ University of Ostrava, Ostrava, Czech Republic
}

Please cite this article as:

Sucháček, J., Koutský, J., Caridad Lopéz del Río, L. and Sed'a, P., 2021. Econometric Analysis of Integration of Selected New EU Member CEE Stock Markets With Global Stock Market and Eurozone: Impact of Global Financial Crisis. Amfiteatru Economic, 23(58), pp. 824-842.
Article History

Received: 22 March 2021

Revised: 9 May 2021

Accepted: 26 June 2021

\section{DOI: $10.24818 / \mathrm{EA} / 2021 / 58 / 824$}

\begin{abstract}
The period of the global financial crisis can be characterized by the spillover of negative innovations among stock markets worldwide. Stock markets in Central Europe were not excluded as they are not isolated from global stock markets. Recently published scientific studies dealing with this theme were mainly focused on the integration of the new EU members' stock markets with the eurozone only. Hence, this paper aims to investigate, compare and interpret integration among stock markets of selected new EU member states in Central Europe (the Czech Republic, Hungary, and Poland), the global stock market and the eurozone equity market within 2004-2018. The added value of this article consists especially in using a wider spectrum of econometric tools (cointegration, VAR model, Granger causality, variance decomposition) and comparison of changes of mutual relationships in three different testing sub-periods to study the dynamics in time. Our research is accomplished via usage of data on daily frequency. Delivered results showed that the degree of integration of Central European stock markets with the US stock market and eurozone significantly increased during global financial crisis. Moreover, stock markets in Central Europe are more integrated with the global stock market than the euro area.
\end{abstract}

Keywords: global financial crisis; Granger causality; integration; stock market; VAR model; variance decomposition.

JEL Classification: F36, G15, G31

* Corresponding author, Jan Sucháček - e-mail: jan.suchacek@econ.muni.cz

\section{Authors' ORCID:}

Jan Suchacek: https://orcid.org/0000-0001-9508-6959

Jaroslav Koutsky: https://orcid.org/0000-0002-2581-8058

Lorena Caridad Lopéz del Río: https://orcid.org/0000-0002-3406-9917

Petr Seda: https://orcid.org/0000-0002-2205-6377 


\section{Introduction}

The process of globalization of the world economy plays a key role in the development of financial markets (Falahaty and Law, 2012). The process of integration of national stock markets can be considered as one of the consequences of those globalization tendencies. It has both negative and positive impacts on financial markets and real economy in general (Schmukler, 2004). Firstly, we should mention the problem of deregulation and new legislation that significantly removes barriers to the flow of financial capital. This process demonstrably contributes to the integration of financial markets (Agrawal, 2017). The possibility of a broader allocation of capital belongs to the positive benefits of financial integration since excessive capital can be allocated to more productive sectors. The efficient allocation of financial resources is also linked to economic growth (Law and Singh, 2014).

The integration of markets may lead to the increase of competition, ensures easier access to various financial products and supports risk diversification. Conversely, some effects of financial integration can be negative. A high degree of integration increases the ability of the outflow of a huge volume of capital from one country to another in a relatively short time. Moreover, it creates a risk of transmission of financial contagion from one market to another one (Li and Giles, 2015). Highly integrated financial markets don't ensure financial stability if entire system is not sturdy enough and flexible to external shocks such as the financial contagion. If financial institutions get into problems, they can undoubtedly contribute to the financial instability of the economy as proven during the period of the recent global financial crisis (Babecký, Komárek and Komárková, 2013).

Financial integration may lead to the growth of the investment opportunities of financial institutions. They can get higher returns at the same level of risk. Contrary to that, their portfolios are not diversified when exposed to the same level of risk so that the whole financial sector can be more sensitive to contagion risk in case of integration (Babecký, Komárek and Komárková, 2013). Strongly integrated markets do not support financial stability if financial system is not resistant to financial shocks coming from abroad. The contagion risk, systemic risk and higher volatility are transmitted faster through the integrated market. It may have the effect of reducing credit to businesses, with the consequent negative impact on the real economy (Popov and Udell, 2010). On the other hand, the major benefits of integration include positive effect on domestic investments and economic growth, improving the efficiency of the financial system, international diversification of risk, growing prudence of market agents and credit ratings (Caridad et al., 2020).

Unpredictable ups and downs in the prices of financial instruments are quite natural in almost every market. Financial crisis and turmoil are not typical for developed financial markets only. Neither developed nor emerging Central European stock markets are excluded from this rule and may sometimes face subsequent instability (Babecký, Komárek and Komárková, 2013). One could observe it during the global financial crisis between 2007 and 2009 that originated in the USA as a financial meltdown and affected countless countries.

Capital markets play an important role in overall economic stability, as confirmed during recent financial and current debt crisis. Hence, both the Czech National Bank and the European Central Bank regularly examine the integration of capital markets (European Central Bank, 2018; Česká národní banka, 2018). The degree of capital market connectivity is an important issue for the new European Union (EU) Member States as these are small open economies, and financial contagion is thus relatively fast in these economies. 
Mutual relations between equity markets play an important role especially for the new EU member states in Central Europe. We focus on the Czech Republic, Hungary, and Poland. Potential financial contagion may expand very rapidly in these economies as evidenced during global financial crisis. For instance, the fund withdrawal led by foreign investors in the Czech stock market exacerbated volatility in the securities market. Polish and Hungarian stock markets are describable in a similar manner (Sed'a, 2012). The Czech Republic, Hungary, and Poland joined the EU in 2004. All these countries are obliged to join the eurozone in the future. Their future joining the eurozone without integration of financial markets can cause economic problems (Vychytilová, 2018). Proper quantitative analysis of the alignment of their financial markets with the eurozone seems to be important. However, we cannot skip shocks coming from the global market (Lehkonen, 2015).

The objective of this article is to describe, compare and interpret integration among stock markets of selected new EU member states in Central Europe, represented by the Czech Republic, Poland and Hungary, global financial market approximated by the U.S. stock market, and the eurozone stock market in 2004-2018 years. The point is to answer the question of whether the development of markets of the new EU member states is affected more by global, regional (eurozone and other Central and Eastern European (CEE) markets) or purely domestic events. Selected econometric methods, such as cointegration, vector autoregression, Granger causality, and variance decomposition will be applied here.

Given the declared aim of this paper, two basic research hypotheses have been formulated:

H1: The global financial crisis affected integration among the Central European stock markets, and with the global stock market in a significant way.

H2: The Central European stock markets are affected by the U.S. stock market rather than the eurozone area.

Both hypotheses are based on the results of previous research. Babecký, Komárek and Komárková (2013) proved that financial integration has been increasing in the Czech Republic, Hungary, and Poland since the end of 1990-ies. During global financial crisis, they observed temporary divergence of Czech stock market from the markets of the euro area. However, they consider just pre-crisis and crisis periods because the data sample covered the period of 1999-2010 only. They analyzed the level of integration of the Czech, Hungarian and Polish markets just with the euro area, not with the global stock market.

The novelty of our article can be seen in three aspects. At first, we applied a relatively wide spectrum of econometric techniques, not just one. It allows us to evaluate whether the results are in harmony or not. Secondly, empirical investigation was carried out on data from three different sub-periods. Previous papers were focused on the comparison of the pre-crisis and crisis periods only. We will especially emphasize the impact of the global financial crisis of 2007-2009 years and compare with other two sub-periods. Thirdly, the previous research was mainly focused on integration with the euro area and within CEE stock markets, not with global stock market.

Our paper will be organized as follows: Section 1 is devoted to a literature review. In Section 2 , econometric methods and approaches applied in this paper will be described. Section 3 is devoted to data samples utilized in this paper. Empirical results and discussion are delivered in Section 4. Section 5 depicts the research findings and concludes this paper. 


\section{Relevant literature review}

In last two decades, an extensive literature has been developed and published on the integration of financial markets. One of the most challenging problems is to investigate the integration of emerging stock markets with developed countries. This question especially lures the attention of central banks. The Czech National Bank regularly publishes analyses of the economic alignment of the Czech Republic with the eurozone area (Česká národni banka, 2018). Similar analyses are periodically examined by the European Central Bank.

Previous research suggested that the degree of interdependence of stock markets of the new EU member countries with the global market and the euro area stock market is growing, but local events are still important for the development of these markets. These papers, however, are only marginally engaged in the issue of mutual interdependence of stock markets of the new EU member states. It is therefore not clear whether these markets are influenced exclusively by national events or are affected more by regional events.

Voronkova (2004) investigated the degree of integration of the Central European stock markets with the eurozone utilizing mainly dispersions of stock indices, regression analysis, yield differentials, and other quantitative methods. They assert mutual integration rapidly increased over time. In addition to this, if some countries joined the eurozone this tendency even strengthened. Babecký, Komárek and Komárková (2010) proved that a rate of integration of stock markets of the new EU members with the euro area has been growing since 2004. Moreover, one cannot omit economic and political events in the global market. Baumöhl and Lyócsa (2014) applied a very similar methodological approach. They reported that the integration process of the new EU member countries showed a growing tendency.

Chaloupka (2012) found out that new EU countries are viewed by investors as one homogeneous Eastern European region rather than individual economies. He proved during the global financial crisis period, the equity markets of the new EU countries were perceived as one homogeneous region since negative information from one stock market significantly influenced developments in other markets. In sum, a rate of interrelationships of stock markets of the new EU countries with global market and the euro area countries has graduated over time. However, in some countries, local shocks still have a significant impact too.

Cevik, Korkmaz and Cevik (2017) applied the asymmetric causality test to CEE stock markets. This causality test indicated only a causal link going from the Czech Republic to Hungary and Poland. Moreover, the presence of financial integration between CEE stock markets and Germany was not observed.

Pietrzak, et al. (2017) quantified the long-term interdependences among Austrian, Czech, Hungarian, German and Polish capital markets. Also, the impact of short-term shocks on those markets was evaluated. The DCC-GARCH model with the conditional $t$-distribution was utilized for calculating the interdependencies among the capital markets in 1997-2015. Furthermore, the analysis of co-integration for interdependencies among markets was performed. Pietrzak, et al. (2017) proposed to include conditional variances of analyzed markets in terms of independent variables in the cointegration models. Their approach allowed to consider short-term market shocks in the cointegration analysis as conditional variance reflects the impact of short-term shocks. Achieved results suggested identifying the long-term path for the course of interdependences. The CEE stock markets can be viewed as a group of markets characterized by a similar long-term path. 
Grabowski (2019) investigated time-varying co-movements between stock markets of the Czech Republic, Hungary and Poland, and capital markets of developed countries in periods of crisis and stability. He applied the VAR-AGDCC-GARCH model and calculated the volatility spillovers. The level of correlation between stock return shocks of the CEE countries increased significantly during global financial crisis, as well as during the euro area sovereign debt crisis. He concluded that CEECs are the recipients of volatility from other countries. From 2004 to 2019, they received much volatility from Germany and the USA.

Put succinctly, the review of literature indicates that results of various authors tend to differ. This is due to the usage of different sample data of different frequencies and periods, and different analytical methods and approaches as well.

\section{Applied methods and data}

In this section, we will depict methods and data that are used for empirical analysis. Mutual relationships will be investigated by Engle-Granger cointegration analysis followed by a vector autoregression model (VAR). This approach will be utilized later to investigate causality in Granger sense. Finally, a variance decomposition approach will be applied. Those methods are commonly used in scientific literature dealing with the financial integration of capital markets. In addition to this, Granger causality and variance decomposition are directly based on estimated VAR models (Engle and Granger, 1987).

\subsection{Cointegration analysis}

Cointegration can be understood as a statistical property of time series. Cointegration theory brought significant innovation in theoretical and practical econometrics. This statistical property of time series has attracted the most interest of financial analytics and macroeconomists in the last 20 years.

In this paper, cointegration analysis will be applied to the stock indexes time series. Two time series are cointegrated if they share a common stochastic drift. More precisely, two time series of stock indexes $x_{t}$ and $y_{t}$ that are both integrated of $\mathrm{I}(1)$ are considered to be cointegrated if there exists a parameter $\omega$ such that time series $u_{t}$, that can be modelled as $u_{t}=y_{t}-\omega x_{t}$, follows a stationary process. According to Arlt and Arltová (2009), time series $u_{t}$ can be considered stationary in its weak or covariance form if the following assumptions hold:

- mean value - $E\left(u_{t}\right)$ has a constant value for all t periods,

- variance - $\operatorname{var}\left(u_{t}\right)$ has also constant value and doesn't change for all t periods,

- covariance $-\operatorname{cov}\left(u_{t_{1}}, u_{t_{2}}\right)=\operatorname{cov}\left(u_{t_{1+h}}, u_{t_{2+h}}\right)$ doesn't change when shifting time for any $h$ too.

If time series $u_{t}$ follows a non-stationary process, parameters $\varphi_{p}$ of regression model $\mathrm{AR}(\mathrm{p})$ that can be written as

$$
u_{t}=\varphi_{1} u_{t-1}+\ldots+\varphi_{p} u_{t-p}+\varepsilon_{t}
$$

are equal to one. 
For this article, the Engle-Granger methodology will be applied to verify the existence of a cointegration vector (Engle and Granger, 1987). Cointegrated time series of indexes follow a mutual trend, or their relationship follows the equilibrium in the long term.

\subsection{VAR model and Granger causality}

Vector autoregressive models or $\operatorname{VAR}(p)$ models represent a very useful, flexible and easily applicable tool when modelling multivariate time series (Lütkepohl, 2005). The VAR approach is commonly utilized for forecasting systems of mutually related time series, and analysis of the dynamic impact of random disturbances on a system of variables. These causal impacts are usually referred to as forecast error variance decompositions.

The VAR model avoids the need for structural modelling by taking into consideration every endogenous variable in the system in terms of functions of lagged values of all endogenous variables that are included in the system (Hamilton, 1994). In our analysis, endogenous variables are considered logarithmic returns of stock indexes. The structure of the model is that each variable (stock index return) is modelled as a linear function of past lags of itself and past lags of the other variables (stock index returns).

Let's assume $(n \times 1)$ vector of stock index returns $R_{t}=\left(r_{1, t}, r_{2, t}, \ldots, r_{n, t}\right)$. VAR $(p)$ model can be written as follows:

$$
R_{t}=\alpha+\Pi_{1} R_{t-1}+\Pi_{2} R_{t-2}+\ldots+\Pi_{p} R_{t-p}+\varepsilon_{t}
$$

for $t=1, \ldots, T$, where $\Pi_{i}$ represent $(n \times n)$ coefficient matrices and $\varepsilon_{t}$ is $(n \times 1)$ vector process of error terms satisfying the following assumptions:

$$
\begin{gathered}
E\left(\varepsilon_{t}\right)=0, \\
E\left(\varepsilon_{t} \varepsilon_{t}^{\prime}\right)=\Omega, \\
E\left(\varepsilon_{t} \varepsilon_{t-k}{ }^{\prime}\right)=0 .
\end{gathered}
$$

In other words, $\varepsilon_{t}$ is an unobservable serially uncorrelated zero-mean white noise process with time-invariant covariance matrix.

The $\operatorname{VAR}(p)$ model also represents a very useful tool that allows us to investigate causality among stationary stock index returns using the Granger test (Granger, 1969). The Granger approach differs from correlation analysis between two scale variables. The conception of Granger causality does not insinuate true causality. It only insinuates the ability to predict or forecast one stock return with the help of other returns.

If a return $r_{1, t}$ is considered to be helpful for forecasting return $r_{2, t}$ then $r_{1, t}$ is said to Grangercause $r_{2, t}$. If this condition is not fulfilled, it is said $r_{1, t}$ to fail to Granger-cause $r_{2, t}$. More formally written, $r_{1, t}$ fails to Granger-cause $r_{2, t}$ if for all $s>0$ the Mean Square Error (MSE) of a forecast of $r_{2, t+s}$ based on $\left(r_{2, t}, r_{2, t-1}, \ldots, r_{2, t-l}\right)$ is the same as the MSE of a forecast of $r_{2, t+s}$ based on $\left(r_{2, t}, r_{2, t-1}, \ldots, r_{2, t-l}\right)$ and $\left(r_{1, t}, r_{1, t-1}, \ldots, r_{1, t-l}\right)$.

The bivariate regression has the following form:

$$
\begin{aligned}
& r_{1, t}=\alpha_{0}+\alpha_{1} r_{1, t-1}+\ldots+\alpha_{l} r_{1, t-l}+\beta_{1} r_{2, t-1}+\ldots+\beta_{l} r_{2, t-l}+\varepsilon_{1, t}, \\
& r_{2, t}=\alpha_{0}+\alpha_{1} r_{2, t-1}+\ldots+\alpha_{l} r_{2, t-l}+\beta_{1} r_{1, t-1}+\ldots+\beta_{l} r_{1, t-l}+\varepsilon_{2, t},
\end{aligned}
$$


for all possible pairs of returns included in the set of variables. Before running the Granger causality test the number of lags to be used in the test regressions according to (4) must be chosen. The Granger test reports $F$-statistics for following joint hypothesis:

$$
H_{0}: \beta_{1}=\beta_{2}=\ldots=\beta_{l}=0
$$

for each equation. The null hypothesis means that $r_{2, t}$ does not cause $r_{1, t}$ in Granger sense in the first regression. Similarly, $r_{1, t}$ doesn't cause $r_{2, t}$ in Granger sense in the second regression.

\subsection{Variance decomposition}

The structural form of the VAR model can be conveniently described by either the impulse response functions or the variance decomposition. We will utilise merely the variance decomposition. The variance decomposition analysis is often used as a prominent tool when interpreting estimated multivariate time series models in financial engineering. Once the VAR model has been estimated and fitted, the variance decomposition approach is usually used to aid an interpretation of the VAR model. The forecast error variance decomposition belongs to one of the very useful tools for evaluation of how shocks reverberate through a system of variables.

Variance decomposition separates the variation in stock index return into component shocks to the VAR model. The variance decomposition indicates the amount of information each return contributes to other return in the autoregression model (Chaloupka, 2012). In other words, this analytical tool determines how much of the forecast error variance of each return can be explained by exogenous innovations of the other returns. When applying variance decomposition, we get information about relative importance of each random shock that may affect the variables in the VAR model.

When using EViews software, we are limited to the Cholesky orthogonal factorizations only. When we alter the ordering of the variables in the VAR model, results may change. For instance, when assuming the VAR ordering, the first-period variance decomposition for the first variable is caused completely by its innovations. It should be added that the forecast standard errors must be the same as those from the Cholesky factorization. It applies if the structural VAR model is just identified. Hence, the forecast standard errors may be different to maintain the adding up property for over-identified structural VAR models.

In brief, the variance decomposition tool allows us to evaluate the importance of different innovations by determining the relative proportion of variance each innovation contributes to the total variance of each return. The results of variance decompositions will be illustrated by figures only. We get combined response graph that illustrates the decomposition of each forecast variance in the form of line graphs measuring relative share of each shock.

\subsection{Data sample}

In this section, the data sample used for empirical analysis will be described. Empirical properties and features of utilized data will be depicted too. Time series of Central European stock markets that include the Czech Republic, Poland and Hungary, and developed markets represented by the USA and the euro area will be applied. We utilized daily data for 
2004-2018 years. It includes altogether 3764 observations. Data were obtained from the websites of relevant stock exchanges. We employed time series of major stock indexes of respective Central European stock markets. We used the PX index for the Czech Republic, WIG20 index for Poland and BUX index in case of Hungary. It serves as a means of approximation of events on national markets. EURO STOXX50 (EUR50) index was chosen as a benchmark market for the eurozone area. This index provides a Blue-chip representation in the eurozone. The index covers a total of 50 stocks from 12 eurozone countries. The S\&P500 index was chosen as a proxy for the global stock market since this index is based on market capitalizations of 500 largest companies having common stock listed on the NYSE.

Respecting the development of investigated market, the basic testing period of 2004-2018 years was divided into 3 sub-periods: pre-crisis, crisis and post-crisis periods. The beginning of the pre-crisis period was chosen as of January 01, 2004, because Central European countries joined the EU in May 2004. The division of the basic testing period into sub-periods is based on the development of the S\&P500 index. On October 9, 2007, the S\&P500 closed at $1,565.15$ points, which was the highest value in more than seven years of history. Therefore, October 9, 2007, was chosen as the end of the pre-crisis period and concurrently the beginning of the crisis period, which was associated with the liquidity crisis (Babecký, Komárek and Komárková, 2013). This term was affected especially by the subprime mortgage crisis that spread to the wider U.S. financial sector and later transformed into a global financial crisis. The resulting situation became acute in September 2008 as evidenced by a period of unusual market volatility reaching the highest levels since 1929 in the USA. The market continued to decline also in 2009. On March 9, 2009, the S\&P500 index reached a 13-year lowest value when closing at 676.53 points. The end of crisis period was set on the 30th of June 2009 when the National Bureau of Economic Research (NBER) in Cambridge, USA announced the end of global financial crisis in the USA. The post-crisis period that starts on the $1^{\text {st }}$ of July 2009 and finishes at the end of 2018 can be characterized by economic stagnation and was accompanied by a debt crisis in many European countries including Central Europe. Figure no.1 demonstrates the development of the S\&P500 index between 2004 and 2018. We aim to compare the degree of integration in all three testing sub-periods as we expect that especially global financial crisis of 2007-2009 may have a significant impact on the integration of financial markets.

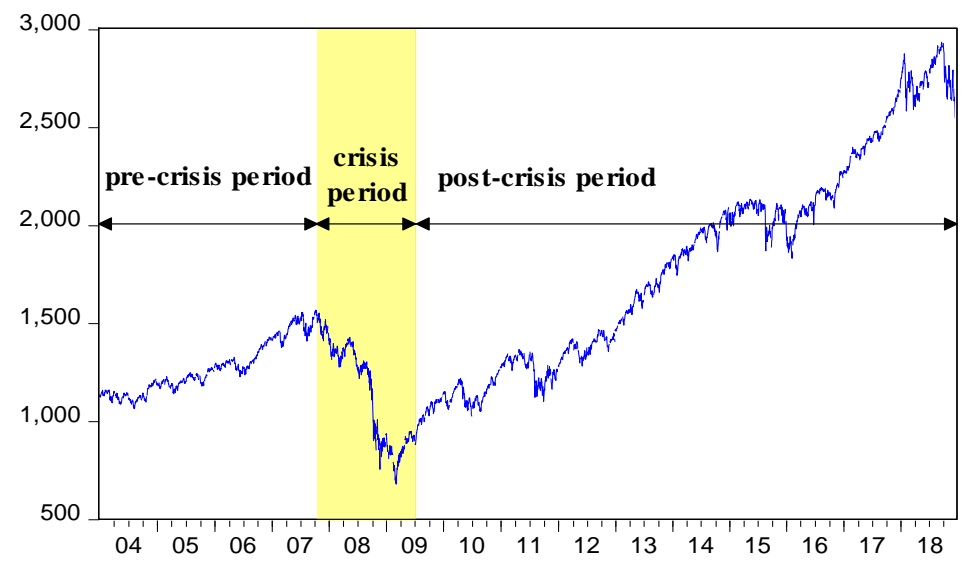

Figure no. 1. Development of S\&P500 index (2004-2018) 
All analyses will be accomplished by using data of daily frequency. Arlt and Arltová (2003) showed that daily data exhibit more volatile behaviour than data of weekly or monthly frequency since some important information can be lost by aggregation. When working with daily data we also get some advantages. Data samples of daily frequency contain more information than data of lower frequency. This may be crucial when investigating the mutual integration of financial markets. Moreover, data of daily frequency can react to new events much faster than data of lower frequency.

In addition to this, some analyses can be applied to stationary data only. The easiest way of changing the data from non-stationary data to a stationary time series is to compute a time series of daily returns. The following conversion into logarithmic returns ensures stationarity property of the daily returns:

$$
r_{t}=\log \left(1+R s_{t}\right)=\log \frac{P_{t}}{P_{t-1}}=\log \left(P_{t}\right)-\log \left(P_{t-1}\right),
$$

where $P_{t}$ and $P_{t-1}$ are values of indexes at time $t$ or $t-1$ respectively, $R s_{t}$ is simple return of the asset, $r_{t}$ means the absolute increment of logarithmic price. We call it logarithmic return.

\section{Empirical results and discussion}

Results of our research will be presented in this section. Empirical analyses presented in this paper were accomplished on sample data representing the individual stock markets with the help of methods described in Section 2. Sample data were analyzed using cointegration analysis, VAR models followed by Granger causality and variance decomposition. All the computations are carried out in EViews software. Significances of estimated parameters are marked in the following way: $1 \%$ significance level is marked with ***, while $5 \%$ significance level is identified by $* *$, and $10 \%$ significance level is marked with *.

\subsection{Cointegration analysis}

Before running the cointegration analysis it is necessary to evaluate whether analyzed time series follows a stationary process or not. For closing values, we cannot reject the hypothesis of the unit root at 5\% significance level (Dickey and Fuller, 1979). On the other hand, in case of logarithmic returns, we can reject the null hypothesis of a unit root. All investigated time series are therefore integrated of $I(1)$. Now it is possible to investigate potential existence of a common trend between pairs of time series. The cointegration analysis was applied to daily closing values of indices. Table no. 1 reports the results of Engle-Granger (EG) test statistics for all three investigated sub-periods. We will consider just those values of EG tests that are significant at least at $5 \%$ significance level.

In the pre-crisis period, the null hypothesis of a unit root in residuals can be rejected just for four pairs of indexes. We observed that Czech market is cointegrated with Hungarian and euro area stock markets and Polish market with the eurozone and the U.S. stock markets. Global financial crisis has changed long term relationships between pairs of markets significantly. Results we achieved show that the null hypothesis of a unit root in residual term can be rejected for additional four pairs of indexes (CZ with USA and POL, HUN with the euro area and US stock market) at $1 \%$ or $5 \%$ significance levels. This supports the hypothesis there were established balanced relationships between more stock markets starting from 2007 than in the pre-crisis period. It seems that more and more stock markets follow a joint trend in times of economic turmoil. 
Table no. 1. Results of Engle-Granger cointegration tests in all sub-periods

\begin{tabular}{|c|c|c|c|c|c|c|}
\hline \multicolumn{3}{|c|}{ SP500 } & \multicolumn{3}{|c|}{ EUR50 } & \\
\hline Pre-crisis & Crisis & Post-crisis & Pre-crisis & Crisis & Post-crisis & \\
\hline-3.71 & $-8.82 * * *$ & $-5.24 * * *$ & $-4.18 * *$ & $-5.34 * * *$ & -3.44 & PX \\
\hline$-4.74 * *$ & $-6.95 * * *$ & -3.57 & $-4.78 * * *$ & $-5.07 * * *$ & -2.47 & WIG20 \\
\hline-3.38 & $-6.79 * * *$ & -0.96 & -3.48 & $-4.19 * *$ & -2.65 & BUX \\
\hline \multicolumn{3}{|c|}{ WIG20 } & \multicolumn{3}{|c|}{ BUX } & \\
\hline-1.30 & $-5.02 * * *$ & $-4.94 * * *$ & $-3.59 * *$ & $-3.08 * *$ & -3.12 & PX \\
\hline & & & -2.43 & $-4.19 *$ & -2.78 & WIG20 \\
\hline
\end{tabular}

Further, in the post-crisis period, cointegration relationships have been observed just for two pairs of indexes only. Those two pairs include just the Czech stock market with Polish and US stock markets. It should be noted that cointegration relations were observed with the euro area market in neither case. Our findings would support the hypothesis that in the period of a global financial crisis local stock markets are rather affected by global events represented by US and euro stock markets. This can be also explained by their higher sensitivity to new information and the gregarious behaviour of investors in times of instability. On the other hand, during the period of economic growth and relative stability, local information plays a more important role in the development of national markets.

\subsection{VAR model and Granger causality}

Results of EG cointegration tests have confirmed long term relationship between some pairs of indexes in some periods. However, cointegration analysis is not able to provide a structural analysis of mutual relationships. That is why in this subsection we will apply VAR models and arising Granger causality tests as described in subsection 2.2. VAR models can be applied to stationary time series only. Logarithmic returns follow the stationary process. Orders of delays in VAR models were identified with the help of likelihood ratio statistics. The HuberWhite estimator was used to estimate the VAR models so that the standard errors are robust to heteroskedasticity. Estimated regression coefficients of VAR models are summarized in Tables no. 2, 3 and 4. These tables include also values of adjusted $R^{2}$ and $F$-statistics that are related to the significance of estimated models. Table no. 2 illustrates the estimation of the $\operatorname{VAR}(2)$ model using data from the pre-crisis period, while the results of the VAR(9) model for the crisis period are presented in Table no. 3, and estimation of the VAR(2) model using data from the post-crisis period are shown in Table no. 4. For simplicity, there are presented just those values of lagged returns that are significant at least at the $10 \%$ significance level.

Results presented in Table no. 2 imply that the most important independent variables in VAR(2) model was especially one day lagged values of US stock market returns in the precrisis period. Moreover, Polish and Hungarian stock market returns were also considerably affected by lagged values of returns of the eurozone stock market. This finding follows the assumption that innovations coming from the U.S. stock market may affect the development of other markets significantly. It should be noted that one day lagged U.S. returns are always statistically significant. In addition to that, estimated coefficients of those returns reached relatively high values. Conversely, the eurozone coefficients reached just negative values. The impact of these two zones is contradictory. The values of adjusted $R^{2}$ are very small so that estimated VAR models can explain only a small share of the total variability in the data sample. It seems that other factors were probably more important. 
Table no. 2. Estimation of VAR(2) model for pre-crisis period

\begin{tabular}{|c|c|c|c|c|c|c|}
\hline & \multicolumn{2}{|c|}{ PX } & \multicolumn{2}{c|}{ WIG20 } & \multicolumn{2}{c|}{ BUX } \\
\hline Variable & BUX_1 & $0.191 * *$ & SP500_1 & $0.360 * * *$ & WIG20_2 & $0.189 * *$ \\
\hline & SP500_1 & $0.560 * * *$ & EUR50_1 & $-0.205 * *$ & SP500_1 & $0.471 * * *$ \\
\hline & & & & & EUR50_1 & $-0.299 * * *$ \\
\hline & & & \multicolumn{2}{c|}{0.075} & EUR50_2 & $-0.263 * * *$ \\
\hline Adj. $R^{2}$ & \multicolumn{2}{|c|}{0.196} & \multicolumn{2}{c|}{3.462} & \multicolumn{2}{c|}{0.134} \\
\hline$F$-stat. & \multicolumn{2}{|c|}{8.369} & \multicolumn{2}{c|}{$<0.001$} & \multicolumn{2}{c|}{$<063$} \\
\hline$p$-value & $<0.001$ & \multicolumn{2}{|c|}{$<$} & \multicolumn{2}{c|}{$<1$} \\
\hline
\end{tabular}

The previous status quo has changed substantially after an outbreak of the financial crisis in October 2007. All Central European indexes became included in all equations of estimated VAR(9) model in terms of independent variables. It implies greater coherence among Central European markets during the financial crisis period. Polish market affected Czech and Hungarian ones while Hungarian returns influenced just the Czech market.

Table no. 3 illustrates that the euro stock market belongs to significant independent variables in every Central European market. Its values are positive in the Hungarian market and negative in the Czech and Polish stock markets. However, it is obvious, that the US stock market plays a key role in the VAR model. US market coefficients reached higher values on average and are always positive. It supports the hypothesis that the Central European stock markets are more integrated with the global stock market than the eurozone as it can be derived from current results. It is also worth noticing that in the period of a global financial crisis the value of adjusted $R^{2}$ has grown considerably. For instance, it achieved a value of nearly $32 \%$ in the case of the Czech index and $25 \%$ of the variability of the Hungarian market. The value of adjusted $R^{2}$ is negligible in the case of the Polish market.

Table no. 3. Estimation of VAR(9) model for crisis period

\begin{tabular}{|c|c|c|c|c|c|c|}
\hline & \multicolumn{2}{|c|}{ PX } & \multicolumn{2}{|c|}{ WIG20 } & \multicolumn{2}{|c|}{ BUX } \\
\hline Variable & BUX_1 & $0.252 *$ & SP500_6 & $0.478 * * *$ & BUX_2 & $-0.331 * *$ \\
\hline & PX_3 & $-0.366 * *$ & EUR50_6 & $-0.396 *$ & BUX_6 & $-0.254^{*}$ \\
\hline & PX_6 & $-0.331 * *$ & & & WIG_6 & $0.306^{*}$ \\
\hline & WIG_8 & $0.382 * *$ & & & SP500_1 & $0.466 * * *$ \\
\hline & SP500_1 & $0.750 * * *$ & & & SP500_6 & $0.383^{*}$ \\
\hline & SP500_5 & $0.398^{*}$ & & & EUR50_1 & $0.496 * *$ \\
\hline & SP500_6 & $0.698 * * *$ & & & EUR50_7 & $0.465 * *$ \\
\hline & SP500_9 & $0.351 * *$ & & & & \\
\hline & EUR50_5 & $-0.469 *$ & & & & \\
\hline & EUR50_6 & $-0.421 *$ & & & & \\
\hline Adj. $R^{2}$ & \multicolumn{2}{|c|}{0.317} & \multicolumn{2}{|c|}{0.067} & \multicolumn{2}{|c|}{0.249} \\
\hline$F$-stat. & \multicolumn{2}{|c|}{2.596} & \multicolumn{2}{|c|}{1.249} & \multicolumn{2}{|c|}{2.142} \\
\hline$p$-value & \multicolumn{2}{|c|}{$<0.001$} & \multicolumn{2}{|c|}{0.128} & \multicolumn{2}{|c|}{0.001} \\
\hline
\end{tabular}


In the post-crisis period, the rate of mutual integration of the Central European markets decreased significantly as demonstrated by Table no. 4. Central European markets are affected mainly by the US. Market. The estimated coefficients are always positive. Eurozone market has an inverse effect with lower values of the estimated coefficient in general. Local markets are not so important. Also, it should be noted that the values of adjusted $R^{2}$ decreased below the pre-crisis values considerably. This fact is supported by a very low value in the case of the Hungarian market.

Table no. 4. Estimation of VAR(2) model for post-crisis period

\begin{tabular}{|c|c|c|c|c|c|c|}
\hline & \multicolumn{2}{|c|}{ PX } & \multicolumn{2}{|c|}{ WIG20 } & \multicolumn{2}{|c|}{ BUX } \\
\hline Variable & BUX_2 & $0.046^{*}$ & BUX_2 & $0.048 *$ & PX_2 & $0.083 * *$ \\
\hline & PX_1 & $-0.091 * * *$ & WIG20_2 & $-0.146 * * *$ & WIG20_2 & $-0.079 * *$ \\
\hline & PX_2 & $-0.062 * *$ & EUR50_1 & $-0.120 * * *$ & EUR50_1 & $-0.099 * *$ \\
\hline & WIG20_2 & $-0.073 * * *$ & SP500_1 & $0.378 * * *$ & EUR50_2 & $-0.098 * *$ \\
\hline & SP500_1 & $0.352 * * *$ & SP500_2 & $0.176 * * *$ & SP500_1 & $0.335 * * *$ \\
\hline & SP500_2 & $0.129 * * *$ & & & SP500_2 & $0.139 * * *$ \\
\hline Adj. $R^{2}$ & \multicolumn{2}{|c|}{0.090} & \multicolumn{2}{|c|}{0.057} & \multicolumn{2}{|c|}{0.035} \\
\hline$F$-stat. & \multicolumn{2}{|c|}{17.949} & \multicolumn{2}{|c|}{11.364} & \multicolumn{2}{|c|}{7.292} \\
\hline$p$-value & \multicolumn{2}{|c|}{$<0.001$} & \multicolumn{2}{|c|}{$<0.001$} & \multicolumn{2}{|c|}{$<0.001$} \\
\hline
\end{tabular}

When having estimated VAR models, it is necessary to test standardized residuals for stationarity, normality, and autocorrelation. The hypothesis of normality was verified again with the help of the Jarque-Bera test. The Jarque-Bera statistics belong in all cases to the critical field so that the corresponding $p$-values are low. Hence, the null hypothesis of the normality of the residual component can be rejected. The null hypothesis of no autocorrelation of a residual component was verified with the help of standard Portmanteau test for autocorrelation and LM autocorrelation test that can be used for testing the $k$-th order autocorrelations. These tests were carried out for up to $9^{\text {th }}$ delays. The null hypotheses were not rejected at 5\% significance level for VAR(2) models in the pre-crisis and post-crisis period. In a crisis period, there was identified a slight $1^{\text {st }}$ order autocorrelation in VAR(9) model residuals. To summarize, the only problem in residual series is associated with a probability distribution. Nevertheless, that property was expectable as we used a data sample of daily frequency. Since our data sample contains hundreds or thousands of observations, we can get approximately the same results as the assumption of normality in the residual term is fulfilled. All inverse roots of autoregressive polynomials in all periods can be found within the unit circle. Estimated VAR models can be further used for testing Granger causality as already described in subsection 2.2. The easiest way is to use values of overall $F$-test and partial $t$-test statistics. However, the EViews software allows us to carry out a Granger causality test directly when having estimated VAR models. Table no. 5 demonstrates the selected results of Granger causality tests. There will be presented just one-way relationships between the US and eurozone stock markets and Central European markets for all subperiods. If we assume 5\% significance level, the results we achieved by Granger causality tests are consonant with results achieved by VAR models. 
Table no. 5. Results of Granger causality tests in all sub-periods

\begin{tabular}{|c|c|c|}
\hline Null hypothesis & Chi square-statistics & Prob. \\
\hline \multicolumn{3}{|l|}{ Pre-crisis period } \\
\hline SP500 returns do not Granger Cause PX returns & $60.401 * * *$ & $<0.001$ \\
\hline EUR50 returns do not Granger Cause PX returns & 1.989 & 0.370 \\
\hline SP500 returns do not Granger Cause WIG20 returns & $26.824 * * *$ & $<0.001$ \\
\hline EUR50 returns do not Granger Cause WIG20 returns & 3.674 & 0.159 \\
\hline SP500 returns do not Granger Cause BUX returns & $33.937 * * *$ & $<0.001$ \\
\hline EUR50 returns do not Granger Cause BUX returns & $9.699 * * *$ & 0.008 \\
\hline \multicolumn{3}{|l|}{ Crisis period } \\
\hline SP500 returns do not Granger Cause PX returns & $46.367 * * *$ & $<0.001$ \\
\hline EUR50 returns do not Granger Cause PX returns & 11.016 & 0.275 \\
\hline SP500 returns do not Granger Cause WIG20 returns & $16.385 *$ & 0.059 \\
\hline EUR50 returns do not Granger Cause WIG20 returns & 7.631 & 0.572 \\
\hline SP500 returns do not Granger Cause BUX returns & $17.885 * *$ & 0.037 \\
\hline EUR50 returns do not Granger Cause BUX returns & $16.349 *$ & 0.060 \\
\hline \multicolumn{3}{|l|}{ Post-crisis period } \\
\hline SP500 returns do not Granger Cause PX returns & $106.926 * * *$ & $<0.001$ \\
\hline EUR50 returns do not Granger Cause PX returns & 0.318 & 0.853 \\
\hline SP500 returns do not Granger Cause WIG20 returns & $90.841 * * *$ & $<0.001$ \\
\hline EUR50 returns do not Granger Cause WIG20 returns & $10.708 * * *$ & $<0.001$ \\
\hline SP500 returns do not Granger Cause BUX returns & $59.883 * * *$ & $<0.001$ \\
\hline EUR50 returns do not Granger Cause BUX returns & $10.359 * * *$ & 0.006 \\
\hline
\end{tabular}

\subsection{Variance decomposition}

When analysing estimated VAR models, one of possible further steps of our investigation is to carry out variance decomposition analysis as described in subsection 2.3. Variance decomposition provides information about relative relevance of each random shock that may influence variables included in the VAR model. Values of adjusted coefficients of determination of both VAR(2) models in pre-crisis and post-crisis periods reached very low values for all indexes. That is why the variance decomposition analysis was applied just for data sample covering the period of global financial crisis. Figures no. 2, 3 and 4 show variance decomposition for all Central European indexes, i.e. PX, WIG20, and BUX.

One can see that the proportion of variability that can be explained by domestic factors varies between $45 \%$ and $100 \%$ in all Central European markets. Proportion of domestic component has a downward trend in all Central European markets. The lowest proportion was recorded in Czech market, around $45 \%$ after 20 days. A similar decrease can be contemplated also in Hungarian market (around 50\%). Further, an impact of the EURO STOXX 50 index was practically negligible in all markets. Its proportion is less than $10 \%$, while global stock market represented by the US index S\&P 500 reached significantly higher values. Innovations coming from the US market were important especially for variance in Hungarian and Czech markets (nearly $30 \%$ or $15 \%$ of variance). Interestingly, nearly $30 \%$ of the proportion of the variability of Czech index can be attributed to events coming from Hungarian market. Polish stock market variance is affected mainly by local factors. 


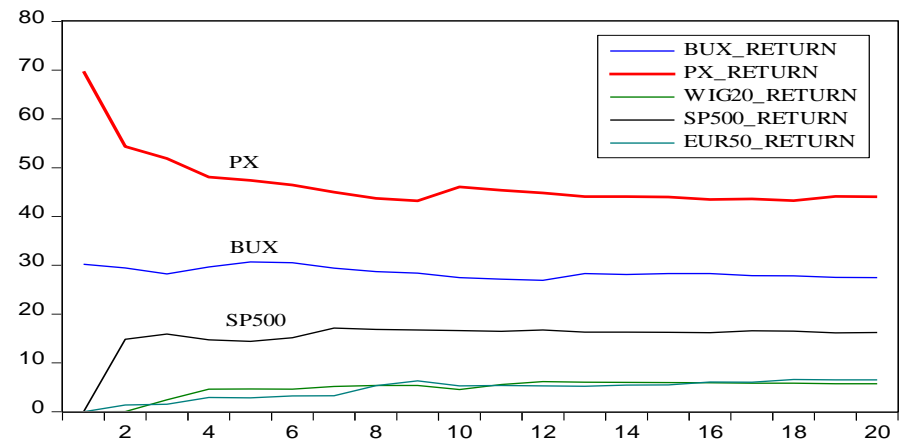

Figure no. 2. Variance decomposition for PX index in crisis period

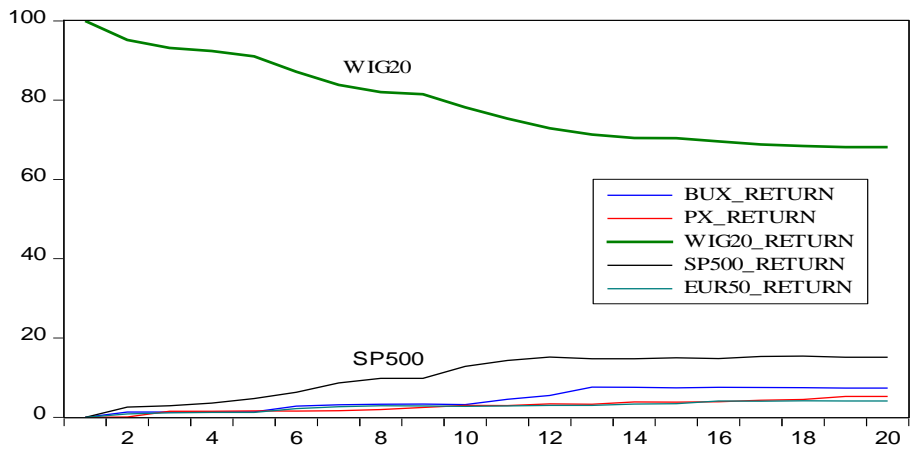

Figure no. 3. Variance decomposition for WIG20 index in crisis period

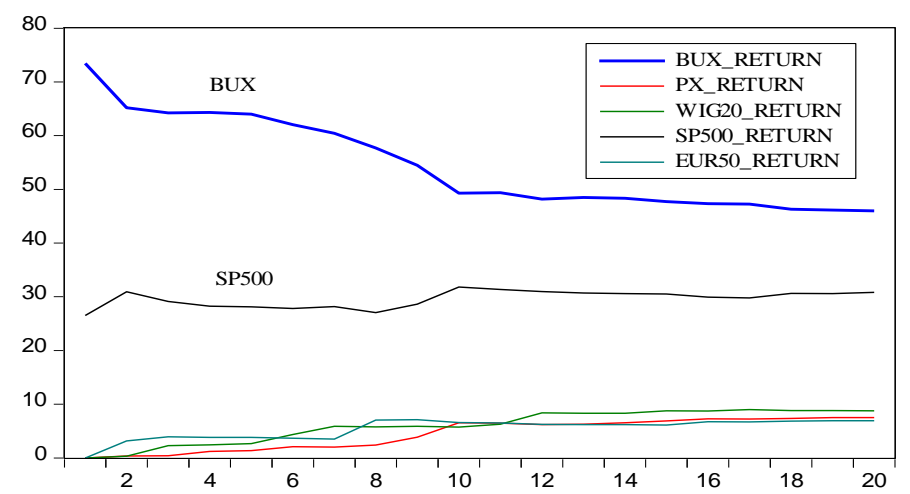

Figure no. 4. Variance decomposition for $\mathrm{BUX}$ index in crisis period

To summarize our findings, local innovations still play a key role when decomposing the variance of Central European stock markets. However, more than one-third of total variability can be ascribed to external innovations in Czech and Hungarian stock markets. 


\subsection{Discussion}

According to previous papers dealing with the integration of CEE stock markets the rate of integration of Central European stock markets with the global market and the eurozone was growing gradually. Nevertheless, local innovations remained as the most meaningful factor. The empirical part of this article delivered more detailed outputs.

Briefly, empirical analysis completed within this paper suggested that Central European equity markets were rather marginally impacted by innovations coming from other markets. Until October 2007, we observed significant integration with the US stock market in all CEE markets, and the eurozone in Poland and Hungary, as supported by all analytical tools utilized. During the global financial crisis, Czech and Hungarian stock markets became more integrated especially with the global stock market and other CEE markets as well. In Poland, the degree of integration with other markets remained at a similar level. In short, following periods of financial instability and economic stagnation have changed the mutual relationships of the Czech and Hungarian stock markets significantly when comparing with the previous sub-period.

The pre-crisis period can be characterized by economic growth and stability in all investigated markets. These facts were reflected by relatively low values of standard deviations when compared with the following periods. The cointegration relationship was not rejected just for 4 pairs of indexes. Thus, it cannot be said that all the markets followed a common trend. The estimated VAR model suggested that returns of Central European markets were usually statistically insignificant and therefore had a relatively small effect on the development of other Central European markets. Euro area influence was more important in Poland and Hungary while global stock market was significant in all markets. It seems that in times of economic growth Central European stock markets are affected mainly by other factors. Granger causality test fully supported conclusions based on VAR model results.

One can observe a greater spillover of shocks across all Central European markets after an outbreak of the global financial crisis between 2007 and 2009. Investors became very sensitive to new information in times of crisis. From October 2007 we saw that existence of cointegration relationships has been observed between four more pairs of stock markets so that stock markets followed a common trend in more cases than in the pre-crisis period. According to estimations delivered by the VAR model, developments in their markets have been becoming increasingly important for the development of other Central European markets. The impact of the US stock market increased significantly in absolute values. Our findings implied that a percentage of the variability in returns that can be explained by the VAR model increased considerably in all stock markets and achieved nearly $32 \%$ for Czech stock market returns. However, the euro stock market started to play a more significant role as well. It must be noted that values of the estimated coefficient are positive for the US market and negative for the eurozone market. These findings were confirmed also by Granger causality test and demonstrated graphically by variance decomposition of all Central European indexes. In the post- crisis period, the degree of integration among Central European stock markets returned to the status quo observed in the pre-crisis sub-period.

As to the integration of Central European stock markets with the global stock market and the eurozone, their importance for the development of Central European markets has grown substantially in the period of global financial crisis. Nevertheless, events coming from global market represented by the U.S. stock market had much greater influence than events coming 
from the euro area. It seems that Central European stock markets are rather affected by innovations coming from the U.S. stock market. This is not surprising at all because the U.S. stock market is the largest one in the world. One can assume that especially negative innovations can be easily transferred to other markets. This would be consistent with Chaloupka (2012) and the hypothesis that in times of crisis markets are more influenced by common events, while in times of growth, local information is more important.

Regarding variance decomposition, we presented just results related to the crisis period as the VAR model had the best explanatory power just in that period. The structure of variance was similar in Czech and Hungarian markets. In Polish market, local events are the most important factors, while in Hungary and the Czech Republic, innovations coming from the US market were more important. The fact that innovations from Hungarian stock market were important for the variance of Czech market in the period of global financial crisis is also remarkable. Similar results were achieved by Chaloupka (2012). This phenomenon is explainable by the state of Hungarian economy. Hungary was considerably hit by the crisis already in 2007. Hungarian authorities were forced to request support from International Monetary Fund and EU. Investors also usually tend to perceive negative innovations more sensitively than positive news. It can be concluded that although we applied different econometric methods the results we achieved were very consistent and compliant with theoretical expectations. It should be stressed that our findings apply only to our data sample.

Our findings have some implications for subjects in capital markets. First, achieved results are important for authorities regulating capital markets and policymakers of the CEE countries in the view of domestic fiscal and monetary politics. If capital markets are integrated, it is necessary to monitor the level of uncertainty in developed stock markets to identify the potential risk of an increase in volatility in their domestic market. It is especially important during times of financial turmoil. Second, our findings may be crucial for portfolio managers and investors. A deeper degree of integration of stock markets and dissemination of financial contagion, as happened in the crisis period, implied changes in trade strategies. If capital markets are not integrated, investors can earn a profit through international portfolio diversification in the long run. Diversification options were the best in pre-crisis period, but worst in time of crisis. Conversely, if capital markets are more integrated, the predictability of each market can be ensured using the information contained in the other capital markets. Another consequence is related to arbitrage opportunities. In an integrated market, investors have opportunities to buy and/or sell equities if they realized that the asset is under-priced in one market. Third, the integration of the stock market runs counter to the weak form of market efficiency, as movements in one market can be used to predict movements in another market. In an integrated market, it can be possible to beat the market when trading in various markets by exploiting price changes in one market to predict the change of the another one.

\section{Conclusions}

In recent years, financial integration has been stimulated by the development and implementation of financial innovations whose use in developed stock markets has contributed to recent global financial crisis. This paper analyzed the process of financial integration, especially in times of financial stability, but also instability caused by global financial crisis. This article aimed to investigate, compare and interpret integration among stock markets of selected new EU member states in Central Europe (the Czech Republic, 
Poland, and Hungary), global financial market and the eurozone area between 2004-2018.

There is abundant evidence that the validity of hypothesis $H_{1}$ cannot be eliminated. Results we observed when doing empirical analysis connote that recent period of global financial crisis has changed a system of interrelationships among Central European stock markets with the US stock market significantly. During pre-crisis period, stock markets were less integrated. When global financial crisis broke out, developments of Central European stock markets became more synchronized with global market. Innovations on global markets became more pronounced within Central European stock markets.

Contrary to that, hypothesis $\mathrm{H}_{2}$ was not confirmed. Regarding mutual interrelations of CEE markets with the eurozone area and global stock markets, it can be summarized that these markets were affected by the U.S. stock market rather than the euro area. This was supported by empirical results achieved. Moreover, central European stock markets may be considered by institutional investors as the monolithic Central Europe area. During global financial crisis, Central European stock markets behaved almost like one homogeneous region.

Main contributions of this paper are as follows:

- The CEE stock markets are integrated with the global stock market rather than the euro area.

- The degree of integration of Czech and Hungarian stock markets with other CEE stock markets, global market and eurozone has increased in the period of the global financial crisis.

- The innovations from the Hungarian stock market had a significant impact on the variance of the Czech market during the crisis.

- In the post-crisis period, the degree of integration of CEE stock markets returned in general to the status quo observed in the pre-crisis sub-period.

- Our findings have some implications for policymakers and investors.

- Our paper is based on the analysis of only three stock markets in CEE. Future investigation should be focused on the analysis of integration for a larger group of markets.

\section{References}

Agrawal, G., 2017. Global Financial Markets Integration: A Comparative Study Between Developed and Emerging Economies. In: S. Raghunath and E. Rose, eds. 2017. International Business Strategy. London: Palgrave Macmillan, pp.227-229.

Arlt, J. and Arltová, M., 2009. Ekonomické časové řady. Praha: Professional Publishing.

Arlt, J. and Arltová, M., 2003. Finanční časové řady. Praha: Grada Publishing.

Babecký, J., Komárek, L. and Komárková, Z., 2013. Financial Integration at Times of Financial Instability. Finance a úvěr - Czech Journal of Economics and Finance, 60(1), pp.25-45.

Babecký, J., Komárek, L. and Komárková, Z., 2010. Finanční integrace v době finanční (ne)stability/Zpráva o finanční stabilitě 2009/2010. [pdf] Praha: Česká národní banka. Available at: <https://www.cnb.cz/export/sites/cnb/cs/financni-stabilita/.galleries/ zpravy_fs/FS_2009-2010/FS_2009-2010_clanek_II.pdf> [Accessed 1 December 2020].

Baumöhl, E. and Lyócsa, Š., 2014. Volatility and dynamic conditional correlations of worldwide emerging and frontier markets. Economic Modelling, [e-journal] 38(C), pp.175-183. https://doi.org/110.1016/j.econmod.2013.12.022. 
Caridad, L., Núñez-Tabales, J., Sed'a, P. and Arencibia, O., 2020. Do Moody's and S\&P firm's ratings differ? Economics and Sociology, [e-journal] 13(4), pp.173-186. https://doi:10.14254/2071-789X.2020/13-4/11.

Česká národní banka, 2018. Analýzy stupně ekonomické sladěnosti České republiky s Eurozónou. [pdf] Praha: Česká národní banka. Available at: $<$ https://www.cnb.cz/export/sites/cnb/cs/menovapolitika/.galleries/strategicke_dokumenty/analyzy_sladenosti_2018.pdf> [Accessed 1 December 2020].

Cevik, E. I., Korkmaz, T. and Cevik, E., 2017. Testing causal relation among central and eastern European equity markets: evidence from asymmetric causality test. Economic Research-Ekonomska Istraživanja, [e-journal] 30(1), pp.381-393. https://doi.org/10.1080/1331677X.2017.1305774.

Chaloupka, J., 2012. Ekonometrická analýza vzájemných vazeb akciových trhů nových členských zemí EU před vypuknutím a po vypuknutí finanční krize. Ekonomická revue Central European Review of Economic Issues, [e-journal] 15(3), pp.157-176. https://doi.org/10.7327/cerei.2012.09.03.

Dickey, D. A. and Fuller, W. A., 1979. Distribution of the estimators for autoregressive time series with a unit root. Journal of the American Statistical Association, [e-journal] 74(366), pp.427-431. https://doi.org/10.1080/01621459.1979.10482531.

Engle, R. F. and Granger, C. W. J., 1987. Co-integration and error correction: representation, estimation and testing. Econometrica, [e-journal] 55(2), pp.251-276. https://doi.org/10.2307/1913236.

European Central Bank, 2018. Financial Integration in Europe. [pdf] Frankfurt am Main: European Central Bank. Available at: <https://www.ecb.europa.eu/pub/pdf/ fie/ecb.financialintegrationineurope201805.en.pdf> [Accessed 1 December 2020].

Falahaty, M. and Law, S. H., 2012. The effect of globalization on financial development in the MENA region. Transition Studies Review, [e-journal] 19(2), pp.205-223. https://doi.org/10.1007/s11300-012-0242-6

Grabowski, W., 2019. Givers or Recipients? Co-Movements between Stock Markets of CEE3 and Developed Countries. Sustainability, [e-journal] 11(22), pp.64959517. https://doi.org/10.1080/1331677X.2017.1305774.

Granger, C. W. J., 1969. Investigating causal relations by econometric models and crossspectral methods. Econometrica, [e-journal] 37(3), pp.424-423. https://doi.org/10.2307/1912791.

Hamilton, J., 1994. Time Series Analysis. Princeton: Princeton University Press.

Law, S. H. and Singh, N., 2014. Does too much finance harm economic growth? Journal of Banking and Finance, [e-journal] 41(C), pp.36-44. https://doi.org/10.1016/ j.jbankfin.2013.12.020.

Lehkonen, H., 2015. Stock market integration and the global financial crisis. Review of Finance, [e-journal] 19(5), pp.2039-2094. https://doi.org/10.1093/rof/rfu039.

Li, Y. and Giles, D., 2015. Modelling Volatility Spillover Effects Between Developed Stock Markets and Asian Emerging Stock Markets. International Journal of Finance and Economics, [e-journal] 20(2), pp.155-177. https://doi.org/10.1002/ijfe.1506.

Lütkepohl, H., 2005. New Introduction to Multiple Time Series Analysis. Springer: Berlin. 
Pietrzak, M. B., Fałdziński, M., Balcerzak, A. P., Meluzín, T., and Zinecker, M., 2017. Shortterm Shocks and Long-term Relationships of Interdependencies Among Central European Capital Markets. Economics and Sociology, [e-journal] 10(1), pp.61-77. https://doi.org/10.14254/2071-789X.2017/10-1/5.

Popov, A. and Udell, G. F., 2010. Cross-border Banking and the International Transmission of Financial Distress during the Crisis of 2007-2008. ECB Working Paper No. 1203, [pdf]. Frankfurt am Main: European Central Bank. Available at: <https://www.ecb.europa.eu/pub/pdf/scpwps/ecbwp1203.pdf> [Accessed 1 December 2020].

Schmukler, S., 2004. Financial globalization: gain and pain for developing countries. Economic Review, 89(2), pp.39-66.

Sed'a, P., 2012. Impact of the Global Financial Crisis on Stock Market Volatility: Evidence from Central European Stock Market. In: J. Ramík and D. Stavárek eds., 2012. Proceedings of 30th International Conference Mathematical Methods in Economics. Karviná: Silesian University, School of Business Administration, pp.787-792.

Voronkova, S., 2004. Equity market integration in Central European equity markets: A cointegration analysis with shifting regimes. International Review of Financial Analysis, [e-journal] 13(5), pp.633-647. https://doi.org/10.1016/j.irfa.2004.02.017.

Vychytilová, J., 2018. Stock market development beyond the GFC: The case of v4 countries. Journal of Competitiveness, [e-journal] 10(2), pp.149-163. https://doi.org/ 10.7441/joc.2018.02.10. 